\title{
The Catholic Church and the Sexual Abuse Crisis
}

\author{
By Pravin Thevathasan \\ London: Catholic Truth Society, 2011. 72 pp.
}

The Catholic Church and the Sexual Abuse Crisis is a 72-page booklet written by Dr. Pravin Thevathasan for the Catholic Truth Society's CTS Explanations series. ${ }^{1}$ This booklet describes the nature, prevalence, likely causes, and consequences of clerical sexual abuse within the Church, as well as the Church's teaching and pastoral response to the crisis. Dr. Thevathasan is a consultant psychiatrist (MRCPsych) and a convert to Catholicism who has authored articles on abortion, euthanasia, and other topics concerning medical ethics and mental health in relation to Catholicism. ${ }^{2}$

This booklet reads like a compendium of frequently asked questions (FAQs) concerning the clerical sexual abuse crisis in the Catholic Church. In effect, this is an encyclopedia of topics, obviously related and linked by the author's attempt to give a fair, honest, and broad-if not comprehensiveintroduction to such a complex and serious subject. Space prevents commenting at length on each of the eighteen topics mentioned in the table of contents, but a few which are relevant to this reviewer's professional practice and scholarship are given extra attention.

\section{Scope and Context of the Abuse}

Dr. Thevathasan begins by describing the scope and context of the crisis, as experienced not only in the United States, which became public news almost a decade ago, but also in Europe (i.e., Ireland, Belgium, Holland, and Germany) over the past few years (25-35). From the beginning, he sets the right tone, offering "no excuses ... to justify the appalling crime of sexual abuse perpetrated by a small number of Catholic priests," and, using the words of Pope Benedict XVI, highlights the seriousness of what happens.

In Pope Benedict's 2010 pastoral letter to the Catholics of Ireland, the Holy Father challenges offending priests to understand the "immense harm" which they had done to victims (3), "profoundly wound[ing] people in their childhood, damaging them for a whole lifetime" (4), and had done "great damage ... to the Church" (3). The pope declares: "You betrayed the trust that was placed in you by innocent young people and their parents . . . forfeited the esteem of the people ... and brought shame and dishonor upon your confreres" (3). The pope also chastises bishops who had made "serious mistakes ... in responding to allegations" and who had failed to protect victims, "at times grievously" (3). The section titled "The Serious Harm Caused by Sexual Abuse" describes how "grievous" the harm from sexual abuse can be.

The section titled "Why Do Some Priests Abuse Minors?" would be better titled "Factors within the Church which Contributed to the Crisis." (I think that the section titled "The Profile of the Offender" actually offers a better introduction to understanding priest offenders.) Among these factors include "an unhealthy clericalism" in which "priests proclaim[ed] themselves rather than the person of Jesus Christ." Another was a "culture of dissent from orthodox

The Linacre Quarterly 78(3) (August 2011): 363-368.

(C) 2011 by the Catholic Medical Association. All rights reserved.

0024-3639/2011/7803-008 \$.30/page. 
Catholic teaching." The author notes that "the most appalling crimes ... took place between the mid-1960s and mid-1980s, a time of profound turmoil, disobedience, and dissent in the Church" (38). Also, the brief section titled "Is Celibacy the Problem?" offers significant evidence that celibacy is not! The work of Philip Jenkins who wrote before the media frenzy of the last decade (1996) is given particular attention.

Additional contributions to clarifying the scope of the crisis are addressed in two sections, the first titled "Is There an AntiCatholic Agenda?" and the one following "Is There a Case Against Pope Benedict?" The brief answers to the questions posed by these section titles are "Yes" and "No," respectively.

Yes, there does appear to be an antiCatholic agenda, notably in the media but also from other sources, which are hostile to the Church's "unwelcome moral teaching" and her continued confrontation with "the culture of death." The author states that "there is certainly a growing intolerance of Christians who take their faith seriously," including assertive efforts to promote the "culture of life." Many forces in society resist the proclamation of "the beauty of chastity and of married love" and vilify those who oppose "explicit sex education, the distribution of contraception to children, ... . child pornography, and sexual tourism," and other evils which turn "children into sexual objects" (54).

And no, there is no evidence that the Holy Father handled the cases "of deviant clergy" in the gravely scandalous manner with which "some bishops" did. In what is the longest single section of the book, Dr. Thevathasan does a thorough job of examining the three most publicized cases of the pope's alleged neglect. As the author summarizes appropriately, it "is clear enough" that at no time did Pope Benedict ignore allegations of sexual abuse" (61). Although having "been accused of being part of the problem," he in fact has been "part of the solution" (56).

Although too often ignored or misunderstood by persons within the Church, not to mention the media and others with- out, the section titled "Church Teaching Regarding the Abuse of Minors" briefly and accurately describes relevant magisterial and canonical writings promoting the welfare of children; and the section titled "The Church and the Protection of Children" shows step taken in the U.S. and the UK and at the Vatican to ensure that there is "no conflict between creating a safe environment for children and defending the basic rights of priests to innocence until proven guilty (63).

Elsewhere, Dr. Thevathasan lists reasons within the Church herself that did contribute to the crisis. Paraphrasing and quoting Benedict XVI's pastoral letter to the Catholics of Ireland, these reasons include:

the neglect of the sacraments, the tendency on the part of priests and religious "to adopt ways of thinking and assessing secular realities without sufficient reference to the Gospel," inadequate procedures for determining the suitability of candidates for the priesthood, insufficient moral and spiritual formation in seminaries, and a misplaced concern for the reputation of the Church. (67)

The unwise use of some of the ideas and practices from psychology and the mental-health field, which may have contributed to the deficiencies in seminaries, are discussed below.

Having acknowledged the preceding, Dr. Thevathasan notes accurately that clerical sexual abuse is not unique to Roman Catholicism. In the section titled "A Problem in Other Denominations and Religions?" the booklet states: "Sexual abuse is a problem affecting all religions" (49) and "is present in all religious denominations" (51; emphases added), and mentions that there are reports of sexual abuse by clerics and authority figures in the Anglican, Protestant, Orthodox, Jewish, Hare Krishna, Hindu, Buddhist, and Muslim faith communities as well as abuse among Jehovah's Witnesses and Mormons (4951). For some denominations, these reports are referenced, for others, merely claimed, e.g., as "well documented reports" (51). 
Further, the author places the crisis in and of the Church-and in and of the churches-in the context of the significant, and even greater, incidence of sexual abuse in secular society as a whole. He reports statistics which "indicate that the sexual abuse of minors is significantly higher in secular society than in the Church." In the U.S., children are at significantly greater risk from sexual abuse by family members and public school employees than by priests (14-15).

\section{Psychology and Mental Health Practitioners Share Some Responsibility for the Crisis}

In the section titled "Sexual Abuse: A Psychiatric Perspective," after distinguishing the terms pedophilia ("a persistent sexual interest in prepubescent children manifested in thought, fantasy and sexual behavior") from hebephilia ("sexual attraction of an adult towards a minor about the age of puberty") and ephebophilia ("sexual attraction of an adult towards a post-pubertal minor") (5), the author reviews various professional opinions common at the time the Church experienced and attempted to respond to her greatest incidences of abuse (the 1960s through the 1980s).

These include the belief that true pedophiles could be "cured," which too often led "to transferring abusive priests from one parish to another, often following psychological evaluation" and treatment (4). As a result, "bishops and religious superiors (often) ... placed abusive priests into therapy and then reassigned them in the mistaken belief that they were no longer a threat to children" (7). Unfortunately, the mental-health professionals serving "abusers" believed that they "could be cured with appropriate therapy. It would indeed appear that many priests were allowed to return to work after the bishop had been advised to permit them to do so by the treating psychologist or psychiatrist" (27), with the result that the priests resumed their abuse.

Another belief mistakenly given the veneer of professional acceptability was "that sexual relationships between children and adults were not necessarily harmful" (8-9; cf. 7-11). In response, the author later appropriately quotes Pope Benedict as stating:

In the 1970s, pedophilia was theorized as something fully in conformity with man and even with children ... (which) was part of a fundamental perversion of the concept of ethos ... maintained-even within the realm of Catholic theology-that there is no such thing as evil in itself or good in itself. .. . Morality is replaced by a calculus of consequences, and in the process it ceases to exist." ( 38 , source of quote not cited)

In the section titled "The Therapeutic Culture," Dr. Thevathasan offers fair criticism that the unwise use of "inappropriate psychology" also contributed to the development of the Church's clerical sexual-abuse crisis. He explains that a "false understanding of 'love' entered into certain seminaries in the 1970s, when various psychological theories replaced spiritual formation programs" (40). He argues that it was a subsequent "loss of faith and a lack of prayer life" which led to so much "sexual scandal among priests" (41).

Often enough, "value-free discussions devoid of reference to moral principles" were conducted. The combination of "self exploration, including exploration of one's sexuality, with value-free 'therapy'" along with a neglect of the "ascetic life of prayer, fasting, and self-denial" led to "disastrous" results. "It appears that some . . . priests and seminarians [who] were told that selfdenial was unhealthy and that it would be better for them to get in touch with their inner selves ... did so by sexually abusing children" (42).

Citing the Linacre Institute's own $A f$ ter Asceticism: Sex, Prayer and Deviant Priests as an important source, ${ }^{3}$ the author declares:

As a consequence of the therapeutic mentality, some seminaries, which ought to have been houses of formation, became houses of malformation. . . . The scandal of clergy sexual 
abuse cannot simply be explained by the presence of a handful of deviant priests. ... A climate of permissiveness was created in certain seminaries and, as a result, sexual misconduct became infectious. (42)

Dr. Thevathasan's critique of the harmful effects of misusing inappropriate theories and techniques of psychology-or at least inappropriately using otherwise appropriate ones-has good company. ${ }^{4}$

\section{Episcopal Paternal Neglect}

I am writing this review over the Father's Day weekend, and the celebration of that event influences what I write here. The accurate observation that "seminaries, which ought to have been houses of formation, became houses of malformation" (42) along with the author's repeated mention of the failure by some bishops to properly supervise and intervene in the lives of offending priests, understates what I think is an important consideration. In effect, too many bishops-and religious superiorsfailed to exercise genuine spiritual paternity for the priests under their authority and for whose formation in and after the seminary they were co-responsible.

It strikes me that so many of the men who later became abusive priests were sent to seminaries which at best were incapable of meeting the human, intellectual, spiritual, and pastoral needs of the men they were entrusted to serve, and I suspect that so many of the men did not really know and were not really known by the bishops who ultimately were responsible for their formation. While the bishop is called to be a spiritual father to everyone in his diocese, priests under his formation and authority deserve a premium of his affirming, paternal care. ${ }^{5}$

I am privileged to work in a seminary helping with the human formation (i.e., the affective maturity) of seminarians. I see firsthand the benefits to a seminary and to the seminarians of having guiding bishops involved not only in the overall life of the seminary, but also knowing and being known personally by the men in formation for their respective diocese.

\section{The Role of Homosexuality}

In the section titled "Is Homosexuality to Blame?" as well as in "Sexual Abuse: A Psychiatric Perspective,” Dr. Thevathasan addresses what he correctly calls "a complex issue" (46). The majority of cases of sexual abuse of minors by priests involved homosexual acts, not pedophilia. "The vast majority of victims have been postpubertal males, over 80 percent in the United States" (44). (Although not cited, I assume that the author is referring to the first John Jay Report.) Referencing B. Clowes, the author states: "in the wider society, of males who sexually abuse minors, only one in seven molest boys. In contrast, in the population of priests who sexually abuse minors, six in seven molest boys" (44). ${ }^{6}$ Clearly, homosexual acts are a significant aspect of the abuse.

Yet, while acknowledging Clowes's "conclusion that there is a 'strong link' between male homosexuality and child sexual abuse," the author immediately states: "It is, however, too simplistic to blame one group of people for the entire crisis" (46). As someone who writes and edits the writings of others in this area extensively, I support Dr. Thevathasan's criticism,

that Clowes ought to have defined more precisely what he means by homosexuality. His sampling methods do not appear to have enabled the inclusion of persons with same-sex attraction who live in accordance with Church teaching. Persons with same-sex attraction are not a homogeneous group, and further research is needed in order to better identify offender profiles. (46)

From my own professional and scholarly experience, I think it is important to emphasize something that Dr. Thevathasan does not. Professional care for those who engage in unchaste behavior may be beneficial, even if it does not "cure" the fundamental problem. On a case-by-case basis, I would expect to find that many of the priest-offenders experienced significant benefits from treatment. Unfortunately, pedophilia appears to be like genuine alcoholism. Recovering alcoholics who are experiencing "serene sobriety" would likely 
describe themselves as better and happier persons, yet realistically and wisely would avoid people, places, and things that would offer them a chance to drink.

In the case of homosexuality ("same-sex attraction" or SSA is the preferred term), those who experience same-sex attraction, regard it as unwanted, and seek professional care to resolve it have significant reason for hope. In addition to the Catholic Medical Association's own Homosexuality $\&$ Hope ${ }^{7}$ there are a number of published accounts by Catholic mental-health professionals $^{8}$ and others ${ }^{9}$ which document that change is possible. Some men and women with unwanted same-sex attraction experience enough change to enable them to get married and have children. Others, experience various degrees of "serene celibacy." Some mention about the professional help and hope that is realistically available for priests who have offended, or may be tempted to offend, would have been a good addition to the booklet.

\section{A more suitable ending?}

I find that the booklet ends awkwardly. The last section of the booklet, titled "Prayer and Reparation," begins in an appropriate and timely way, by mentioning that "in their 2011 pastoral letter Towards Healing and Renewal the Irish bishops have written that they have committed themselves to prayer and fasting . . . in reparation for abuse by clergy and the failure of some bishops to respond to the crimes" (68). The last lines of this last section end by reminding the reader:

Most of us have encountered many good and holy priests who try to live up to their vocation. We need to pray every day for them and for more good vocations to the priesthood. How can we save our souls without the sacraments? How can we get to heaven without priests? (69)

I applaud Dr. Thevathasan's love for the Church's priests and his inclusion of that section in the booklet. Yet, given the booklet's title and the range of topics it discusses, I would have preferred that The Catholic Church and the Sexual Abuse Crisis end as it began, with a quote by Bene- dict XIV. A (in my opinion) more suitable ending may be found one or several pages earlier.

Quoting from the Holy Father's 2010 interview with Peter Seewald, ${ }^{10}$ Pope Benedict states:

It is important that we first take care of the victims and do everything that we can to help, support, and heal them. Secondly, such acts must be prevented by the proper selection of candidates for the priesthood. Thirdly, the perpetrators must be punished and barred from any opportunity to repeat such acts." (65)

Another fitting ending would be the author's quote of the Holy Father's address to victims of abuse and their families in his pastoral letter to the Catholics of Ireland ${ }^{11}$ :

You have suffered grievously, and I am truly sorry.... I know some of you find it difficult even to enter the doors of a church after all that has occurred ... yet Christ's own wounds, transformed by his redemptive sufferings, are the very means by which the power of evil is broken and we are reborn to life and hope. I believe deeply in the healing power of his self-sacrificing love even in the darkest and most hopeless situations to bring liberation and the promise of a new beginning. (67)

Following this quote, Dr. Thevathasan notes that the pope "then asks the victims not to look at the sinful individuals who make up the Church but to the person of Christ who is at the very heart of the Church and who was himself a victim of injustice and $\sin "(67)$.

\section{Some Final Thoughts}

While not a comprehensive or a meticulously referenced tome, The Catholic Church and the Sexual Abuse Crisis offers a fair overview and presentation of the most important issues that the Church has faced and continues to face concerning the clerical abuse of minors. From my own knowledge of professional and popular literature, the author is accurate in his "big picture" account, including his critiques of psychology 
and the mental-health professions, although the document is a bit frustrating to a professional accustomed to having sources of any stated facts duly cited. Also, a number of the books cited in the text and none of the papal, episcopal, or other Church documents mentioned are included in the references at the end. But what the booklet lacks in scholarly or professional referencing, it makes up for in the breath, overview, and reasonable accuracy of the topics covered.

Overall, the frequent use of quotes by the Holy Father helps the booklet stay focused and provides an informal structure, by which Dr. Thevathasan offers a good introduction to the tragic reality of the sexual abuse crisis in the Catholic Church and her sincere efforts to address the harm caused by the crisis and to prevent future harm.

Philip M. Sutton, Ph.D. Licensed Marriage and Family Therapist Licensed Clinical Social Worker South Bend, Indiana Licensed Psychologist Detroit, Michigan

\section{Notes}

${ }^{1}$ http://www.cts-online.org.uk/.

${ }^{2}$ See http://www.christendom-awake.org/pages/ pravin/pravin-thevathasan.htm.

3 The Linacre Institute, After Asceticism: Sex, Prayer and Deviant Priests (Bloomington, IN: The Linacre Institute, 2006).

${ }^{4}$ Cf. William R. Coulson, "Full Hearts and Empty Heads: The Price of Certain Recent Programs in Humanistic Psychology," in The Nature and Tasks of a Personalist Psychology, ed. James Dubois (Lanham, MD: University Press of America/Institute for Personalist Psychology, 1995), 59-86; Benedict J. Groeschel, Spiritual Passages: The Psychology of Spiritual Development "for Those Who Seek" (New York: Crossroad Publishing, 1983); Philip Jenkins, Pedophiles and Priests: Anatomy of a Contemporary Crisis (New York: Oxford University Press, 1996), ch. 5, "Psychology and Spirituality"; Paul Vitz, Psychology as Religion: The Cult of Self-Worship, 2nd ed. (1977; Grand Rapids, MI: Eerdmans, 1994).

${ }^{5}$ Cf. Conrad Baars, "The Affirming Bishop," in I Will Give Them a New Heart: Reflections on the Priesthood and the Renewal of the Church, eds. Suzanne M. Baars and Bonnie N. Shayne (Staten Island, NY: The Society of St. Paul/Alba House, 2008).

${ }^{6}$ B.W. Clowes, "Homosexuality and the Church Crisis” (2010), http://www.lifesitenews.com/ ldn/2010_docs/Homosexuality_Church_Crisis2.pdf.

${ }^{7}$ Catholic Medical Association, Homosexuality \& Hope: Questions and Answers about SameSex Attraction (2008), http://www.cathmed. org/issues_resources/publications/position_ papers/homosexuality_and_hope/; idem, Homosexuality \& Hope: Statement of the Catholic Medical Association (2000).

8 Conrad Baars, “The Homosexual's Search for Happiness," in Baars and Shayne, I Will Give Them a New Heart; Rick Fitzgibbons, "The Origins and Therapy of Same-Sex Attractions Disorder," in Homosexuality and American Public Life, ed. Christopher Wolfe (Dallas: Spence Publishing, 1999), 85-97; Joseph Nicolosi, Shame and Attachment Loss: The Practical Work of Reparative Therapy (Downers Grove, IL: InterVarsity Press, 2009) ; Gerard Van den Aardweg, The Battle for Normality: A Guide for (Self-)Therapy for Homosexuality (San Francisco: Ignatius Press, 1997).

${ }^{9}$ Stanton Jones and Mark Yarhouse, Ex-Gays? A Longitudinal Study of Religiously Mediated Change in Sexual Orientation (Downers Grove, IL: InterVarsity Press, 2007); National Association for Research and Therapy of Homosexuality (NARTH) Scientific Advisory Committee, "What Research Shows: NARTH's Response to the American Psychological Association's (APA) Claims on Homosexuality," Journal of Human Sexuality 1 (2009): 1-128.

${ }^{10}$ Peter Seewald and Pope Benedict XVI, Light of the World: The Pope, the Church and the Signs of the Times (San Francisco: Ignatius Press, 2010).

${ }^{11}$ Pope Benedict XVI, pastoral letter to the Catholics of Ireland (2010), http://www.vatican.va/holy_father/benedict_xvi/letters/2010/ documents/hf_ben-xvi_let_20100319_churchireland_en.html. 